\title{
Short Communication: Morphology and genetic characteristics of potential citrus rootstock in Indonesia
}

\author{
FARIDA YULIANTI ${ }^{1,2, v}$, AFIFUDDIN LATIF ADIREDJO ${ }^{2}$, LITA SOETOPO $^{2}$, SUMERU ASHARI $^{2, v \varphi}$ \\ ${ }^{1}$ Indonesian Citrus and Subtropical Fruits Research Institute, Indonesian Agency for Agricultural Research and Development. Jl. Raya Tlekung No. 1, \\ Junrejo, Batu 65321, East Java, Indonesia. Tel.: +62+341-592683, Fax.: +62-341-593047, `email: adiraf212@ gmail.com. \\ ${ }^{2}$ Department of Agronomy, Faculty of Agriculture, Universitas Brawijaya. Jl. Veteran, Malang 65145, East Java, Indonesia. Tel.: + 62-341-569984, \\ »email: sumeru.fp@ub.ac.id
}

Manuscript received: 6 October 2020. Revision accepted: 29 September 2020

\begin{abstract}
Yulianti F, Adiredjo AL, Soetopo L, Ashari S. 2020. Short Communication: Morphology and genetic characteristics of potential citrus rootstock in Indonesia. Biodiversitas 21: 5514-5520. Study on variability among the citrus rootstock genotypes is very important to classify and utilize citrus germplasm resources. The genetic variability would greatly assist the breeders in genotypes identification to develop database and maintain the germplasm repositories in Indonesia. It would also be helpful for stakeholders to choose the right rootstock. The aim of the study was to identify the morphology and genetic variability among three potential citrus rootstocks in Indonesia. Morphological and molecular techniques were used to characterize three citrus rootstocks potential in Indonesia. Characteristics of plant, leaves, flowers, fruits, seeds, and genomic DNA polymorphisms were used to characterize three potential citrus rootstocks (Japansche citroen (JC), Citrumelo and Kanci). Morphological characterizations were based on Descriptors for Citrus (IPGRI 1999). Genetic variabilities were conducted using seven specific markers for biotic and abiotic stresses (VP, CMA, PIP1a, PIP1b, PIP2, osmotin, and Y65). The important characters of citrus rootstock for growers were tree shape, tree growth habit, number of seed, seed polyembryony, and tolerance to biotic and abiotic stresses. JC has spheroid tree shape with spreading growth habit, while Citrumelo and Kanci have ellipsoid tree shape with erect growth habit. These characters may influence scion vigor and size. All of rootstocks observed have high number of seed and polyembryony. These rootstocks amplified PIPs and osmotin markers and could not amplify VP, CMA, and Y65 marker. These plants thought to have the characteristic of tolerance to drought stress with formation of aquaporin and osmotin but susceptible to salinity and Citrus tristeza virus.
\end{abstract}

Keywords: Citrumelo, genetic, Japansche citroen, Kanci, morphology, rootstock

Abbreviations: JC: Japansche citroen; DNA: Deoxyribonucleic Acid; CTAB: Cetyltrimethylammonium Bromide; TE: Tris-Ethylene Diamine Tetra acetic Acid; PCR: Polymerase Chain Reaction; CTV: Citrus Tristeza Virus

\section{INTRODUCTION}

Citrus is one of the most economically important fruit crops in the world, belonging to the subfamily Aurantioideae of the family Rutaceae. It is widely distributed throughout the tropical and subtropical regions. As an agricultural country, Indonesia has 255 Citrus varieties with $43 \%$ are mandarin (Citrus reticulata Blanco), $4 \%$ are tangerine (C. nobilis Lour.), $0.7 \%$ are sweet orange $(C$. x sinensis (L.) Osbeck), $14.3 \%$ are sour orange $(C$. $\times$ aurantium L.), $15 \%$ are pummelo (C. maxima (Burm. F.) Merr), and 23\% are rootstock, lime, lemon, and other types of the species $C$. medica $\mathrm{L}$. Total production of mandarin citrus in Indonesia in the year 2018 are 2.408 .043 tons (BPS-Statistics Indonesia 2019).

The sustainability of the citrus industry depends on yield, fruit quality, and harvesting date. The ability to diversify citrus production is the use of the appropriate rootstocks. The selection of a rootstock should be for the purpose of enhancing the merits of a scion, or adapting it to its total environment. Rootstocks play a crucial role in determining orchard efficiency in fruit crops. The role of rootstocks and its use in fruit crops have significant impact on fruit crop production by influencing canopy architecture, nutritional uptake, flowering, yield, and fruit quality. Moreover, it can confront biotic and abiotic stresses (Balal et al. 2012; Nimbolkar et al. 2016; Albrecht et al. 2018; Santana et al. 2018). Choosing the right rootstock and scion combination is an important factor that can result in higher economic returns.

In over 70 major crops, selection for root and shoot system traits have been decoupled through the process of grafting. Grafting is an ancient horticultural technique that creates a composite plant by surgically attaching the shoot bud from one plant (the scion) to the stocks, joining their vascular and cambial systems (Migicovsky et al. 2019). Rootstock selection should be based on soil adaptability, soil $\mathrm{pH}$, biotic and abiotic pressure, desired tree spacing and size control, and rootstock-scion combination (Castle et al. 2016; Albrecht et al. 2018). Rootstocks have also to be acceptable nursery plants and to show good and prolonged compatibility with scion varieties (Spiegel-Roy and Goldschmidt 1996). 
Evaluation of genetic diversity and relationship among citrus rootstocks is a great importance activity in identification of genetic resources. At present, morphological study is still considered important and has been deployed as an initial step for cultivar identification and diversity assessment (Rodríguez-Garay et al. 2009; Elameen et al. 2011). Although many molecular techniques have been developed in studying the genetic diversity, the practical of morphological characters in horticultural plant species could be an essential component since most of the horticultural characters cannot be evaluated through molecular markers (Singh et al. 2010; Susandarini et al. 2013). Furthermore, the technique is relatively cheaper and easier to conduct. Many previous authors (Dorji and Natural 2011; Nikoumanesh et al. 2011; Malik et al. 2012; Marboh et al. 2015; Neves et al. 2018; Gora et al. 2018) used morphological and/or molecular diversity as an independent or complementary to genetic diversity in citrus.

Study on citrus rootstock characterization in Indonesia is still limited. The study on variation among the citrus rootstock genotypes is very important to classify and utilize the rootstocks. The aim of the study was to identify the morphology and genetic variability among three potential citrus rootstocks in Indonesia. The information provided herein was developed from observation data of the rootstocks planted in Indonesia. The genetic variability would greatly assist the breeders in cultivar identification to develop database and maintain the germplasm repositories of Indonesian Citrus rootstock varieties. It would also be helpful for the growers to choose the right rootstock.

\section{MATERIALS AND METHODS}

Three Citrus rootstock, Japansche citroen (JC) or 'Rangpur' lime (C. Xlimonia Osbeck), Citrumelo ( $C$. paradisi Macf. cv. Duncan x Poncirus trifoliata (L.) Raf) and Kanci (Fortunella sp.) mother plants used in the present study were obtained from field of Indonesian Citrus and Subtropical Fruits Research Institute (ICISFRI). The experiment was carried out from June 2019 to December 2019.

\section{Procedures}

Morphological characterization

Description of three citrus rootstocks mother plants were based on Descriptors for Citrus (IPGRI 1999) consisted following qualitative observations: six parameters of tree morphology (tree shape, tree growth habit, vegetative life cycle, density of branches, branch angle and spine density on adult tree), nine parameters of leaves (shoot tip color, shoot tip surface, leave division, intensity of green color of leaf blade, leaf lamina attachment, leaf lamina shape, leaf lamina margin, absence/presence of petiole wings and petiole wing shape), six parameters of flowers (arrangement of flowers, flower position, flower type, color of petal, length of anthers relative to stigma, and color of anther), ten parameters of fruits (fruit shape, shape of fruit base, shape of fruit apex, fruit skin color, fruit surface texture, adherence of mesocarp to endocarp, albedo color, fruit axis, crosssection shape of axis and pulp color), and six parameters of seeds (number of seed/fruit, seed shape, seed surface, seed color, cotyledon color, and seed embryony).

\section{Genetic characterization}

DNA was extracted from young leaves using CTAB protocol (Doyle 1991). The DNA concentration was measured by nanodrop (Infinite 200Pro, Tecan, Switzerland). The samples were diluted with TE buffer to $50 \mathrm{ng} / \mathrm{L}$ for PCR reactions. The PCR reaction consisted of $25 \mathrm{ng}$ of genomic in a $25 \mu \mathrm{L}$ PCR reaction $(12.5 \mu \mathrm{L}$ MyTaq mix, $25 \mu \mathrm{M}$ forward and reverse primer (Table 1), up to $25 \mu \mathrm{L}$ water). PCR conditions consisted of $95^{\circ} \mathrm{C}$ for 1 min; 35 cycles of $95^{\circ} \mathrm{C}$ for $15 \mathrm{~s}, 60^{\circ} \mathrm{C}$ for $15 \mathrm{~s}$ and $72^{\circ} \mathrm{C}$ for 10s; and one cycle of $72^{\circ} \mathrm{C}$ for $10 \mathrm{~min}$. PCR reactions were performed on a The Eppendorf 6331 Nexus Gradient MasterCycler. PCR products containing $1 \mu \mathrm{L}$ loading dye were separated by electrophoresis on $2 \%$ agarose gel. $1 \mathrm{~kb}$ Gene ruler (Fermentas International Inc., Germany) was loaded in the first lane of each gel to determine the size of amplified bands. Electrophoresis was carried out at 100 volts for 1 hour and photographed using UV transilluminator (BioRad Gel Documentation System, USA).

Table 1. Primers used for genetic characterization

\begin{tabular}{|c|c|c|c|c|c|}
\hline $\begin{array}{c}\text { Primer } \\
\text { name }\end{array}$ & Sequences & $\begin{array}{c}\text { Specific } \\
\text { character }\end{array}$ & Target genes & Gene code & $\begin{array}{c}\text { Specific } \\
\text { band (bp) }\end{array}$ \\
\hline $\mathrm{VP}$ & $\begin{array}{l}\text { F:GCATATGCTCCCATCAGTG } \\
\text { R:CAGGCTCCTGTCTGTTTGAG }\end{array}$ & Salt tolerance & $\begin{array}{l}\text { Citrus sinensis pyrophosphate-energized } \\
\text { vacuolar membrane proton pump }\end{array}$ & XM_006453055.2 & 831 \\
\hline CMA & $\begin{array}{l}\text { F:GTTGCTGATGCTACAGATG } \\
\text { R:CCTCTCTCTCTTCTTTACCG }\end{array}$ & Salt tolerance & $\begin{array}{l}\text { Citrus clementina plasma membrane } \\
\text { ATPase }\end{array}$ & XM_006450103.2 & 805 \\
\hline PIP1a & $\begin{array}{l}\text { F: GACACTCGGCCTGTTCTTG } \\
\text { R: TCCGGTAATTGGGATGGTAG }\end{array}$ & $\begin{array}{l}\text { Drought } \\
\text { tolerance }\end{array}$ & Citrus sinensis putative aquaporin PIP1 & MK084791.1 & 346 \\
\hline PIP1b & $\begin{array}{l}\text { F:AGGATTACACGGAGCCACCT } \\
\text { R:TGCTTTTGGATTTGGACACG }\end{array}$ & $\begin{array}{l}\text { Drought } \\
\text { tolerance }\end{array}$ & Citrus sinensis putative aquaporin PIP1 & MK084789.1 & 156 \\
\hline PIP2 & $\begin{array}{l}\text { F:TGTGTTCATGGTTCACTTGG } \\
\text { R:TGAATGGTCCAACCCAGAAG }\end{array}$ & $\begin{array}{l}\text { Drought } \\
\text { tolerance }\end{array}$ & Citrus sinensis putative aquaporin PIP2 & MK084797.1 & 137 \\
\hline Osmotin & $\begin{array}{l}\text { F:CAACGACCTCTCCTCCTACG } \\
\text { R:ACAGCTCGTCCGTACCAAAC }\end{array}$ & $\begin{array}{l}\text { Drought } \\
\text { tolerance }\end{array}$ & Citrus sinensis osmotin-like protein & XM_006488230.3 & 218 \\
\hline Y65 & $\begin{array}{l}\text { F: GCATCCCTCTTCCTAATTCACA } \\
\text { R: TCTGCCAAGCCTGAAACATC }\end{array}$ & CTV resistance & $\begin{array}{l}\text { Poncirus trifoliata citrus tristeza virus } \\
\text { resistance gene }\end{array}$ & AF278857.1 & 1336 \\
\hline $\mathrm{PC}$ & $\begin{array}{l}\text { F: TGTTCCAAGCTCTTTCTCTG } \\
\text { R: CACCACTCGGAATCTCATC }\end{array}$ & Ploidisation & Citrus sinensis plastocyanin & XM_006473661.3 & 107 \\
\hline
\end{tabular}




\section{RESULTS AND DISCUSSION}

\section{Morphological characters}

\section{Tree morphology}

Observations regarding tree morphological characters are presented in Table 2. Citrumelo and Kanci have ellipsoid tree shape, erect tree growth habit, and wide branch angle, differ with JC that have spheroid tree shape, spreading tree growth habit, and narrow branch angle. JC and Kanci were evergreen plants, and Citrumelo were deciduous ones. JC and Citrumelo have dense high spine density and Kanci have narrow one on adult tree. All of rootstock have dense of branches (Table 2, Figure 1).

\section{Leaf morphology}

Observations regarding leaf morphology in three citrus rootstocks are presented in Table 2 and Figure 2. The three rootstocks have different leaf forms. JC and Kanci have the same leaf division, leaf lamina attachment, and petiole wings characters. JC and Citrumelo have the same leaf lamina margin character. All of their shoot tip surfaces are the same, i.e. glabrous. The intensity of green color in leaves of JC was dark green (NN 137A, RHS Color chart) while Citrumelo and Kanci were medium green (Green group 137A, RHS Color chart). Kanci has larger leaf than JC and Citrumelo. The average leaf area of Kanci, JC, and Citrumelo was $34.42,24.32$ dan $18.04 \mathrm{~cm}^{2}$, respectively. Based on chlorophyll index assessment, JC has larger chlorophyll index than Citrumelo and Kanci, namely 68.99, 52.93, and 35.84, respectively.

\section{Flower morphology}

Observations regarding flower morphology in three citrus rootstocks are presented in Table 2 and Figure 3. All of the rootstocks investigated showing hermaphrodite flower. Citrumelo and Kanci have solitary flowers, white petal, and anthers that longer than stigma and JC have inflorescence flowers, purple petal, and anthers that same length to stigma. Kanci has different color of anthers, which is pale yellow, while JC and Citrumelo have yellow ones.

\section{Fruit morphology}

JC, Citrumelo and Kanci fruits have the same shape, i.e. spheroid. Variations occur in the character of shape of fruit base, shape of fruit apex, fruit skin color, fruit surface texture, adherence of albedo to pulp, albedo color, fruit axis color, and pulp color (Table 2, Figure 4). The JC and Kanci fruits have skin color of fruits at ripe physiologically, i.e. orange, while the Citrumelo is yellow. JC and Citrumelo oranges are ripe physiologically at the age of 8-9 months after anthesis, while Kanci is at 4 months after the anthesis. Kanci could be fruiting throughout the year, while JC and Citrumelo only bear fruit once with flower induction occur in the beginning of the rainy season.
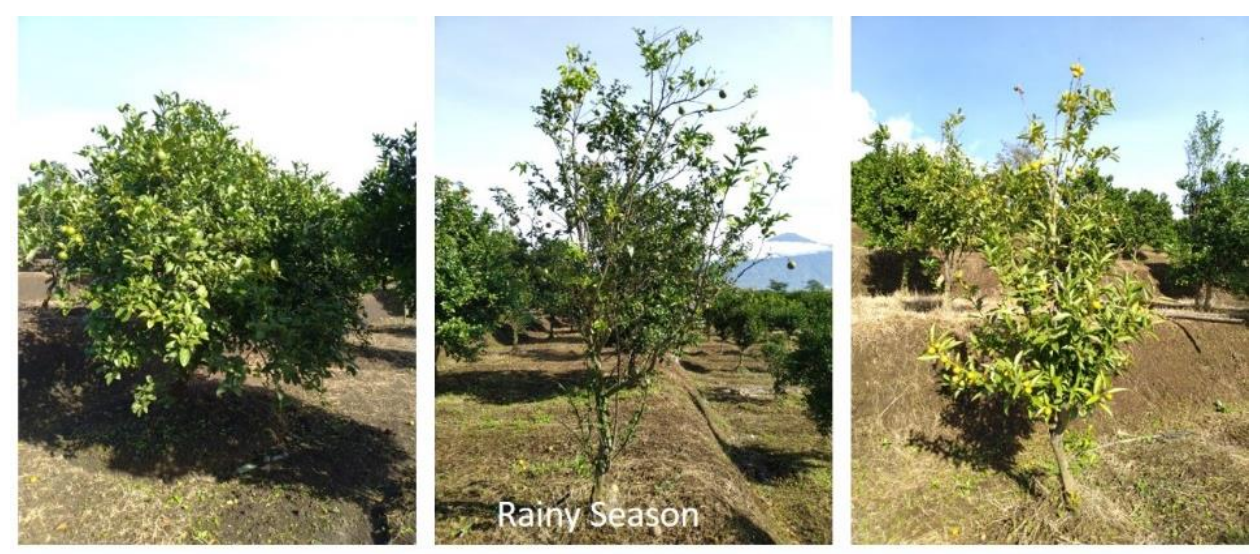

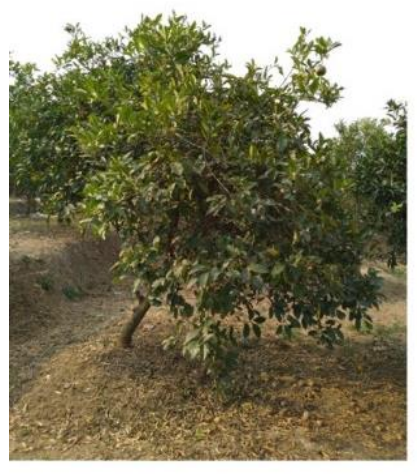

A

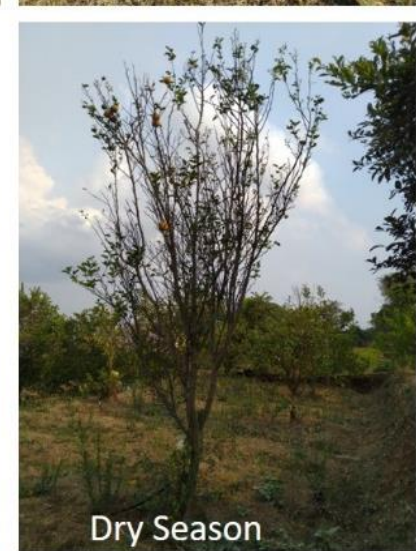

B

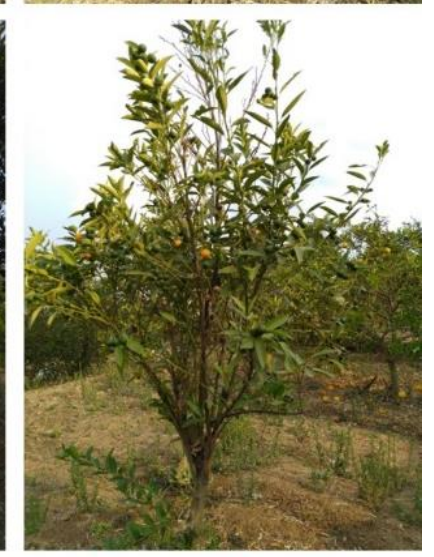

C

Figure 1. Tree performance of: A. Japansche citroen (JC), B. Citrumelo, and C. Kanci at rainy (above) and dry seasons (below) 


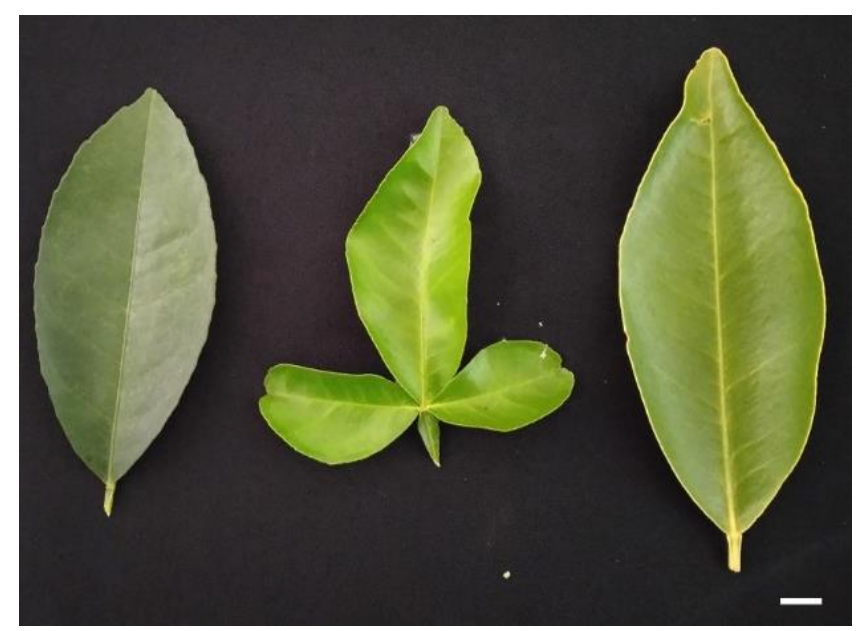

A

B

C

Figure 2. Leaf performance of: A. Japansche citroen (JC), B. Citrumelo ,and C. Kanci. Bar $=1 \mathrm{~cm}$

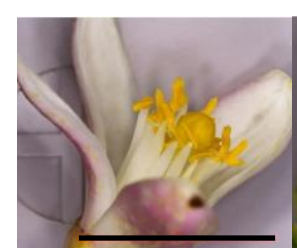

A

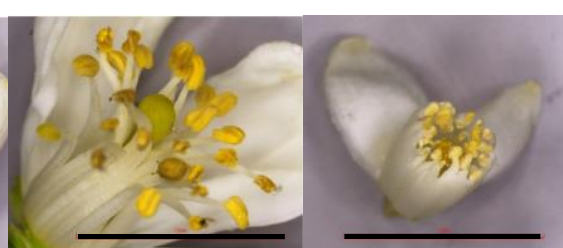

B

C
Figure 3. Flower performance of: A. Japansche citroen (JC), B. Citrumelo, and C. Kanci. Bar $=1 \mathrm{~cm}$

\section{Seed morphology}

Observations regarding seed morphology in three citrus rootstocks are presented in Table 2 and Figure 5. Based on the observations, all of three types of rootstock have seeds with varying characters. JC and Citrumelo are seedier than Kanci. JC has same seed shape, seed surface, and cotyledon color as Kanci and different from Citrumelo. All of seed produced by the rootstocks are polyembryony. Seed characteristics are important to citrus rootstock, especially those related to characters number and polyembryony of the seeds.

\section{Genetic characters}

Specific markers related to the character of resistance to abiotic stress and biotic stress were used to characterize the citrus rootstocks observed. The results of marking specificity tests (primer blast) indicate that specific genes will be amplified at certain band sizes (Table 1). Electrophoresis results of DNA amplicons of citrus rootstocks using specific markers are presented in Figure 6. The size of the DNA band is in accordance with the results of the prediction of specific bands as indicated by the arrow. The results show that the JC, Citrumelo, and Kanci were unable to amplify all of the markers tested. The three types of plants could not amplify VP, CMA, and Y65 markers. At the VP and CMA markers, amplification

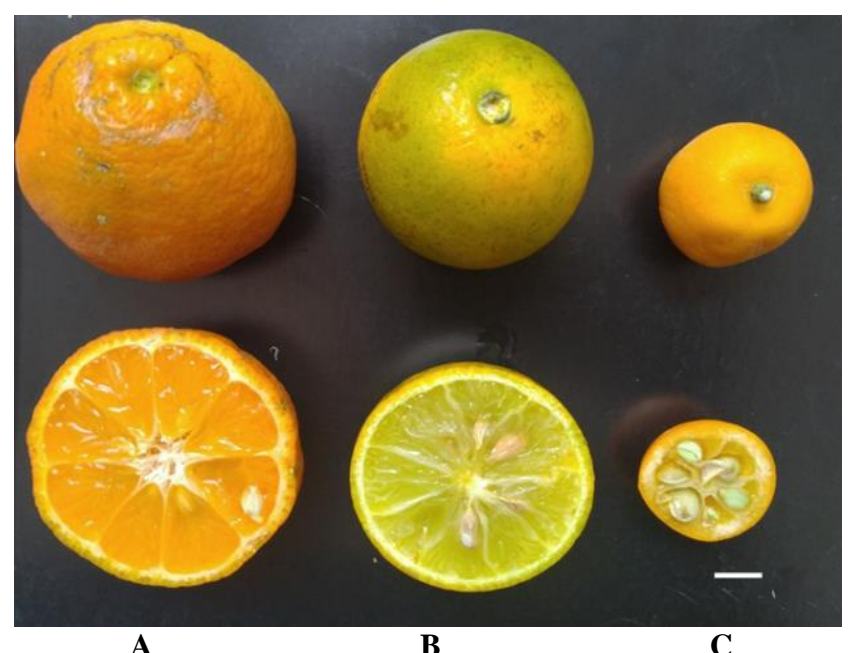

$\mathbf{A}$

B

C

Figure 4. Fruit performance of: A. Japansche citroen (JC), B. Citrumelo , and C. Kanci. Bar $=1 \mathrm{~cm}$

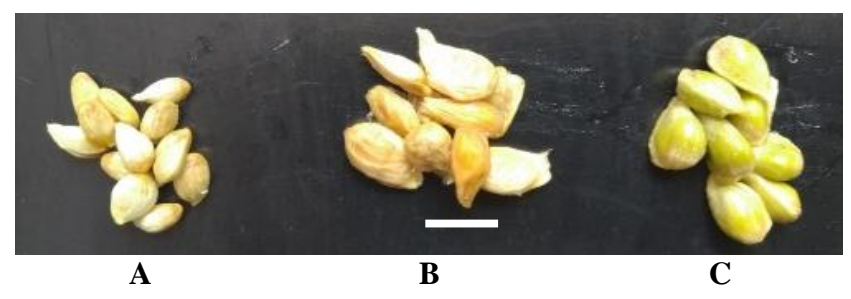

Figure 5. Seed performance of: A. Japansche citroen (JC), B. Citrumelo, and C. Kanci. Bar $=1 \mathrm{~cm}$

occurred but the amplicon did not match with the target gene. At the Y65 markers, there was no amplification. This shows that the three types of plants did not have resistance to salinity stress caused by the Citrus sinensis pyrophosphate-energized vacuolar membrane proton pump and the Citrus clementine plasma membrane ATPase. The three types of plants also did not have resistance to Citrus tristeza virus as expression of the Poncirus trifoliata gene putative disease resistance gene (pY65). The results of the amplification using markers PIP1a, PIP1b, PIP2, and osmotin show the presence of an amplicon according to the size of the target gene band. This shows that the JC, Citrumelo and Kanci plants were thought to have the characteristic of tolerance to drought stress with formation of aquaporin.

\section{Discussion}

The analysis of rootstock samples with morphological and molecular markers was very useful and informative in assisting the breeders in cultivar identification to develop database and maintain the germplasm repositories of Indonesian citrus rootstock varieties. For breeders, all characters were very useful for developing new varieties, but for growers, the important characters of citrus rootstock were number of seed, seed polyembryony, tree shape, tree growth habit, and tolerance to biotic and abiotic stress. 
Table 2. Morphology of Japansche citroen (JC) (C. xlimonia Osbeck), Citrumelo [C. xparadisi Macfad. x Poncirus trifoliata (L.) Raf.] and 'Kanci' (Fortunella sp.)

\begin{tabular}{|c|c|c|c|}
\hline Traits & Japansche citroen (JC) & Citrumelo & Kanci \\
\hline \multicolumn{4}{|l|}{ Tree } \\
\hline Tree shape & Spheroid & Ellipsoid & Ellipsoid \\
\hline Tree growth habit & Spreading & Erect & Erect \\
\hline Vegetative life cycle & Evergreen & Deciduous & Evergreen \\
\hline Density of branches & Dense & Dense & Dense \\
\hline Branch angle & Narrow & Wide & Wide \\
\hline Spine density on adult tree & High & High & Narrow \\
\hline \multicolumn{4}{|l|}{ Leaf } \\
\hline Shoot tip color & Purple & Green & Green \\
\hline Shoot tip surface & Glabrous & Glabrous & Glabrous \\
\hline Leaf division & Simple & Trifoliate & Simple \\
\hline Intensity of green color of leaf blade & Dark & Medium & Medium \\
\hline Leaf lamina attachment & Sessile & Brevipetiolate & Sessile \\
\hline Leaf lamina shape & Elliptic & Lanceolate & Lanceolate \\
\hline Leaf lamina margin & Dentate & Dentate & Entire \\
\hline Absence/presence of petiole wings & Absent & Present, medium & Absent \\
\hline Petiole wing shape & - & Obdeltate & - \\
\hline \multicolumn{4}{|l|}{ Flower } \\
\hline Arrangement of flowers & Inflorescence & Solitary & Solitary \\
\hline Flower/inflorescence position & Terminal & Axillary, Terminal & Axillary, Terminal \\
\hline Flower type & Hermaphrodite & Hermaphrodite & Hermaphrodite \\
\hline Color of petal & Purple & White & White \\
\hline Length of anthers relative to stigma & Medium & Longer & Longer \\
\hline Color of anther & Yellow & Yellow & Pale Yellow \\
\hline \multicolumn{4}{|l|}{ Fruit } \\
\hline Fruit shape & Spheroid & Spheroid & Spheroid \\
\hline Shape of fruit base & Concave & Convex & Truncate \\
\hline Shape of fruit apex & Mammiform & Rounded & Rounded \\
\hline Fruit skin (epicarp) color & Orange & Green-Yellow & Orange \\
\hline Fruit surface texture & Rough & Smooth & Smooth \\
\hline $\begin{array}{l}\text { Adherence of albedo (mesocarp) to pulp } \\
\text { (endocarp) }\end{array}$ & Weak & Strong & Weak \\
\hline Albedo color & Orange & Yellow & Orange \\
\hline Fruit axis & Hollow & Solid & Hollow \\
\hline Cross-section shape of axis & Irregular & Round & Irregular \\
\hline Pulp (flesh) color & Orange & Yellow & Orange \\
\hline \multicolumn{4}{|l|}{ Seed } \\
\hline Number of seed/fruit & $10-19$ & $10-19$ & $5-9$ \\
\hline Seed shape & Ovoid & Clavate & Ovoid \\
\hline Seed surface & Smooth & Wrinkled & Smooth \\
\hline Seed color & Cream & Brown & Green \\
\hline Cotyledon color & Green & Cream & Green \\
\hline Seed embryony & Polyembryony & Polyembryony & Polyembryony \\
\hline
\end{tabular}

Number of seed and seed polyembryony in citrus rootstock is related to the ease, expense, and consistency of propagation. Seed polyembryony is an important trait for breeding and commercial multiplication of citrus rootstocks (Castle 2010). Polyembryony in citrus is a type of facultative apomixis wherein simultaneous development of embryos of nucellar origin co-exists in the same seed containing sexual embryo. Nucellar embryony is considered to be an essential trait for the propagation of genetically uniform plants (Kishore et al. 2012). The ease of seed propagation is one of citrus rootstock selection criterion (Castle et al. 2016).

Today, breeding of citrus rootstocks aimed to create rootstocks that can reduce tree size. Size-controlling rootstocks are important for higher density orchards, and rootstocks that induce scion precocity are needed for significant cropping to begin early (Castle 2010). Tree shape and tree growth habit characters of rootstock may influence scion vigor and size. In this study, Citrumelo and Kanci had ellipsoid tree shape and erect growth habits, meanwhile, JC had spheroid tree shape and spreading growth habit. The ellipsoid tree shape and erect growth habit caused narrow canopy. This character is important for higher density orchards than the wide one. Citrus scion grafted on Citrumelo has smaller canopy than grafted on Rangpur lime (Domingues et al. 2018). Other researchers reported that citrus scion grafted on Citrumelo and Rangpur lime had the same canopy volume (Gonzatto et al. 2011; Bacar et al. 2017). The use of Fortunella as rootstock caused tree size and canopy volume of citrus scion smaller than other rootstocks (Ono and Hirose 1987; Donadio et al. 2019). However, the Fortunella is a subtropical citrus, adaptation within the tropical area such as in Indonesia is still to be examined. 


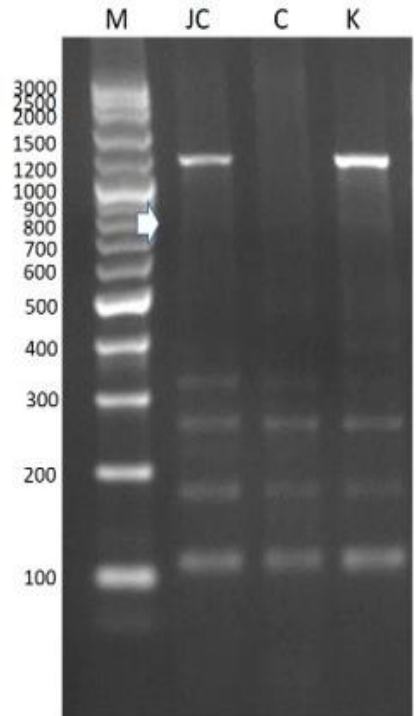

VP

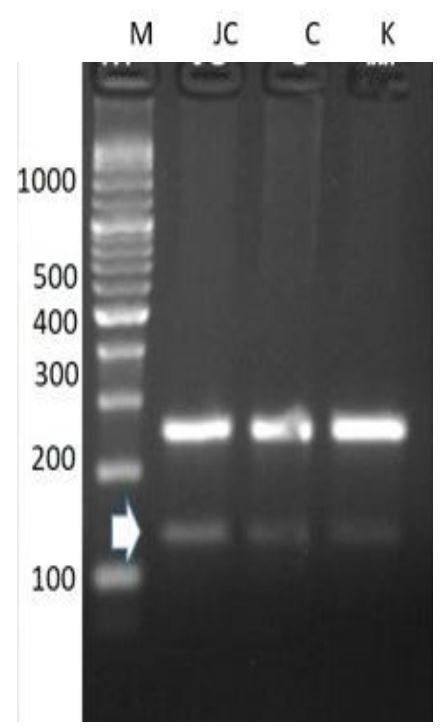

PIP2

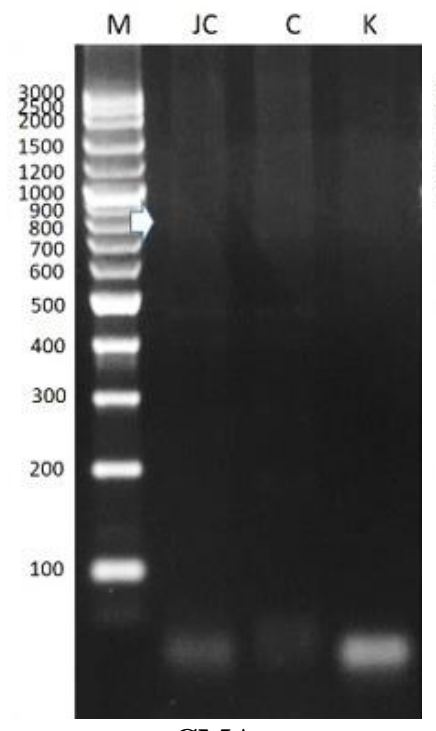

CMA

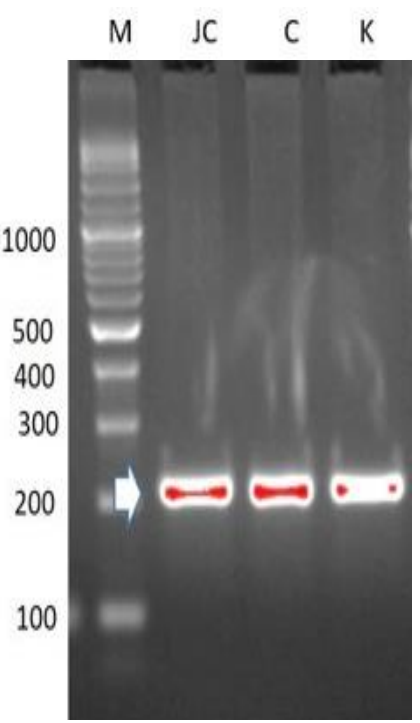

Osmotin

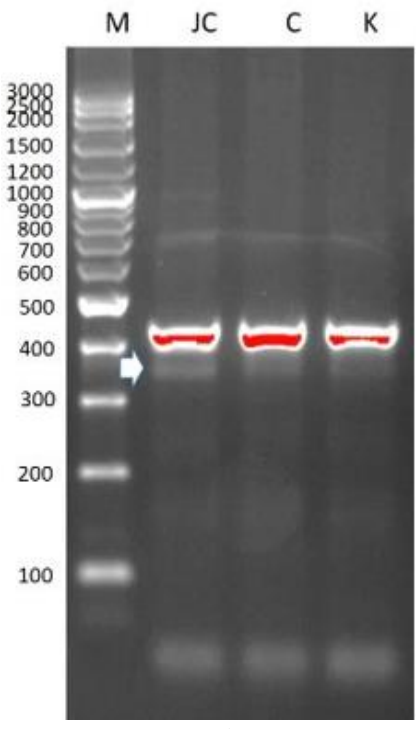

PIP1a

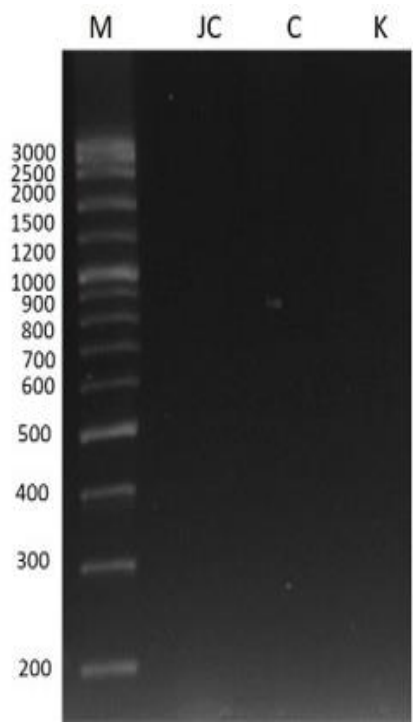

Y56

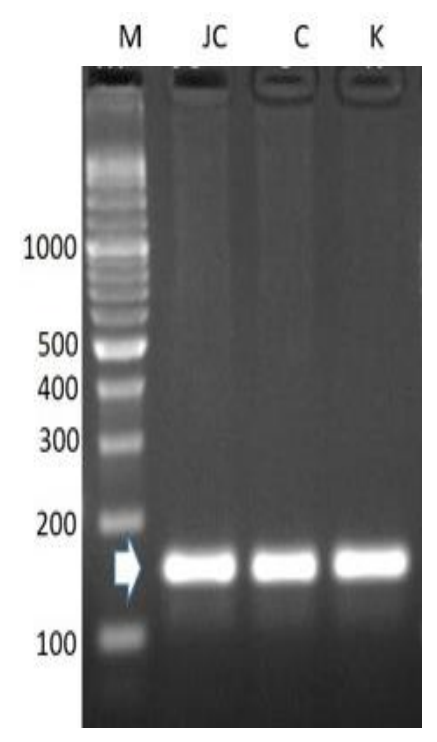

PIP1b

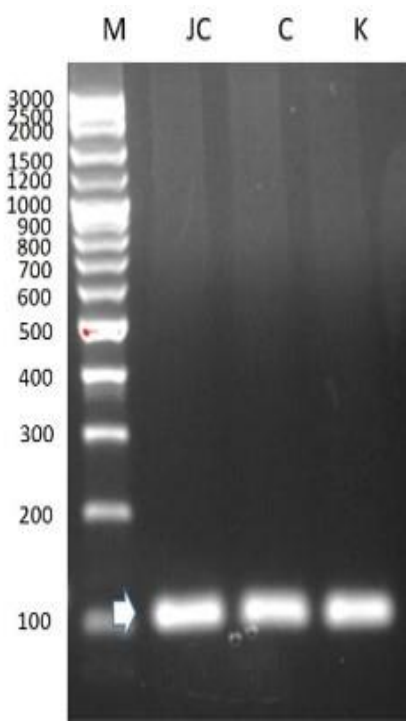

PC

Figure 6. DNA amplification of Japansche citroen (JC) (C. Xlimonia Osbeck), Citrumelo (C) [C. xparadisi Macfad. x Poncirus trifoliata (L.) Raf.] and 'Kanci' (K) (Fortunella sp.) using eight specific markers (arrow: band-specific location)

The resistance of citrus rootstock to biotic and abiotic stresses also made into attributes as a rootstock selection criterion. In this study, all of rootstocks observed did not have resistance gene to tristeza virus and salinity that evidenced by unamplified DNA on specific markers. On the other hand, all rootstocks have resistance to drought stress that was evidenced by amplified DNA on PIP and osmotin markers. PIP and osmotin markers are specific markers for detecting genes linked to aquaporin and osmotin, respectively. Aquaporins, a highly conserved superfamily of major intrinsic proteins, play key roles in regulation of movement of water and other small molecules across membranes (Yaneff et al. 2015; Wei et al. 2019).
Osmotin is an abundant multifunctional cationic protein that has adapted to low osmotic potential environments. Moreover, it has a function in osmoregulation and food preservation (Hakim et al. 2018). Both of these proteins are believed to be related to plant drought tolerance.

In conclusion, we have confirmed that JC, Citrumelo, and Kanci have characteristic to be used as citrus rootstock. All rootstock observed have high number and polyembryony of seed. These plants were also thought to have the characteristic of tolerance to drought stress but susceptible to salinity and Citrus tristeza virus. The three rootstocks have different tree shapes and tree growth habits may influence scion vigor and size. 


\section{ACKNOWLEDGEMENTS}

The authors would like to thank Indonesia Citrus and Subtropical Fruits Research Institute, Batu, Indonesia for providing the plant materials and the Indonesian Agency for Agricultural Research and Development for financial support.

\section{REFERENCES}

Albrecht U, Alferez F, Zekri M. 2018. Citrus Production Guide Rootstock and Scion Selection. IFAS Extension HS 1308: 1-3.

Bacar ELC, Neves CSVJ, Leite Junior RP, Yada IFU, Tazima ZH. 2017. 'Jaffa' sweet orange plants grafted onto five rootstocks. Revista Brasileira de Fruticultura 39 (5): e-200. DOI: 10.1590/0100 29452017200.

Balal RM, Khan MM, Shahid MA, Mattson NS, Abbas T, Ashfaq M, Garcia-Sanchez F, Ghazanfer U, Gimeno V, Iqbal Z. 2012 Comparative studies on the physiobiochemical, enzymatic, and ionic modifications in salt-tolerant and salt-sensitive citrus rootstocks under $\mathrm{NaCl}$ stress. J Am Soc Hortic Sci 137:8 6-95.

BPS-Statistics Indonesia. 2019. Statistics of Annual Fruit and Vegetable Plants. BPS, Jakarta. [Indonesian]

Castle WS. 2010. A career perspective on Citrus rootstocks, their development, and commercialization. HortScience 45:11-15.

Castle WS, KD Bowman, JW Grosser, SH Futch, JH Graham. 2016. Florida Citrus Rootstock Selection Guide. IFAS Extension HS 1260: 1-3.

Domingues AR, Neves CSVJ, Yada IFU, Leite Junior RP, Tazima ZH 2018. Performance of 'Cadenera' orange trees grafted on five rootstocks. Revista Brasileira de Fruticultura 40 (4): e-764. DOI: 10.1590/0100-29452018764

Donadio LC, Lederman IE, Roberto SR, Stucchi ES. 2019. Dwarfingcanopy and rootstock cultivars for fruit trees. Revista Brasileira de Fruticultura 41:1-12.

Dorji K, Natural R. 2011. Assessment of morphological diversity for local mandarin (Citrus reticulata Blanco.) accessions in Bhutan. Technology 7: 485-495.

Doyle J. 1991. DNA Protocols for Plants. In: Hewitt GM, Johnston AWB Young JPW (eds.). Molecular Techniques in Taxonomy. Springer, Berlin.

Elameen A, Larsen A, Klemsdal SS, Fjellheim S, Sundheim L, Msolla S, Masumba E, Rognli OA. 2011. Phenotypic diversity of plant morphological and root descriptor traits within a sweet potato, Ipomoea batatas (L.) Lam., germplasm collection from Tanzania. Genet Resour Crop Evol 58: 397-407. DOI: 10.1007/s10722-0109585-1

Neves CG, do Amaral DOJ, de Paula MFB, de Nascimento LS, Costantino G, Passos OS, Santos MA, Ollitrault P, Gesteira AS, Luro F, et al. 2018. Characterization of tropical mandarin collection: Implications for breeding related to fruit quality. Scientia Horticulturae 239: 289-299. DOI: 10.1016/j.scienta.2018.05.022

Gonzatto MP, Kovaleski AP, Brugnara EC, Weiler RL, Sartori IA, de Lima JG, Bender RJ, Schwarz SF. 2011. Performance of "Oneco" Mandarin on six rootstocks in South Brazil. Pesquisa Agropecuaria Brasileira 46: 406-411.
Gora JS, Kumar R, Sharma BD, Ram C, Kumar K. 2018. Determination of morphological diversity for seed and seedling characteristics in citrus rootstocks. Intl J Chem Stud 6: 2921-2926.

IPGRI. 1999. Descriptor for Citrus. International Plant Genetic Resources Institute, Rome, Italy.

Kishore K, Monika N, Rinchen D, Lepcha B, Pandey B. 2012. Polyembryony and seedling emergence traits in apomictic citrus. Scientia Horticulturae 138: 101-107. DOI: 10.1016/j.scienta.2012.01.035

Malik SK, Rohini MR, Kumar S, Choudhary R, Pal D, Chaudhury R. 2012. Assessment of genetic diversity in sweet orange [Citrus sinensis (L.) Osbeck] cultivars of India using morphological and RAPD markers. Agric Res 1: 317-324. DOI: 10.1007/s40003-0120045-3

Marboh ES, AK Singh, AK Dubey, J Prakash. 2015. Analysis of genetic variability among citrus (Citrus spp.) genotypes using morphological traits. Indian J Agric Sci 85: 203-211.

Migicovsky Z, Harris ZN, Klein LL, Li M, McDermaid A, Chitwood DH, Fennell A, Kovacs LG, Kwasniewski M, Londo JP, et al. 2019. Rootstock effects on scion phenotypes in a 'Chambourcin' experimental vineyard. Hortic Res 6: 64. DOI: 10.1038/s41438-0190146-2

Nikoumanesh K, Ebadi A, Zeinalabedini M, Gogorcena Y. 2011. Morphological and molecular variability in some Iranian almond genotypes and related Prunus species and their potentials for rootstock breeding. Scientia Horticulturae 129: 108-118. DOI: 10.1016/j.scienta.2011.03.017

Nimbolkar PK, Awachare C, Reddy YTN, Chander S, Hussain F. 2016. Role of rootstocks in fruit production - a review. J Agric Engineer Food Technol 3: 183-188.

Ono SU, KA Hirose. 1987. Rootstock studies for citrus varieties in Japan. Japan Agric Res Quart (JARQ) 20: 253-259.

Rodríguez-Garay B, Lomelí-Sención JA, Tapia-Campos E, GutiérrezMora A, García-Galindo J, Rodríguez-Domínguez JM, Urbina-López D, Vicente-Ramírez I. 2009. Morphological and molecular diversity of Agave tequilana Weber var. Azul and Agave angustifolia Haw. var. Lineño. Ind Crops Prod 29: 220-228. DOI: 10.1016/j.indcrop.2008.05.007

Santana LGL, Souza ES, Passos OS, Gesteira AS, Ledo CAS, Filho WSS 2018. Vigor and mortality of citrus progenies with potential use as rootstocks. Scientia Agricola 75: 339-345. DOI: 10.1590/1678-992X2016-0455

Singh H, Rattanpal HS, Sidhu GS, Chahal T. 2010. Study on physiomorphological characteristics among six rangpur lime (Citrus limonia Osbeck.) strains. J Tree Sci 29: 48-56.

Spiegel-Roy P, Goldschmidt EE. 1996. The Biology of Citrus. Cambridge University Press, New York.

Susandarini R, Subandiyah S, Rugayah, Daryono BS, Nugroho LH. 2013. Assessment of taxonomic affinity of Indonesian pummelo (Citrus maxima (Burm.) Merr.) based on morphological characters. Amer J Agric Biol Sci 8: 182-190.

Wei Q, Ma Q, Ma Z, Zhou G, Feng F, Le S, Lei C, Gu Q. 2019. Genomewide identification and characterization of sweet orange (Citrus sinensis) aquaporin genes and their expression in two citrus cultivars differing in drought tolerance. Tree Genet Genomes 15: 17. DOI: 10.1007/s11295-019-1321-1

Yaneff A, Vitali V, Amodeo G. 2015. PIP1 aquaporins: Intrinsic water channels or PIP2 aquaporin modulators?. FEBS Lett 589: 3508-3515. 